\title{
UJI PEMATAHAN DORMANSI MENGGUNAKAN ASAM SULFAT BERDASARKAN VIABILITAS DAN VIGOR BENIH PALA (Myristica fragrans Houtt.)
}

\author{
Philia Ch. Latue ${ }^{1)}$, Henny L. Rampe ${ }^{1)}$, Marhaenus Rumondor ${ }^{1)}$ \\ ${ }^{1)}$ Program Studi Biologi FMIPA UNSRAT Manado, 95115 \\ Email: Christilatue@yahoo.co.id; Hennyrampe@unsrat.ac.id; Marhaenusrumondor66@unsrat.ac.id
}

\begin{abstract}
ABSTRAK
Tanaman pala (Myristica fragrans Houtt.) termasuk salah satu tanaman rempah asli Indonesia yang bernilai ekonomis. Daerah penghasil tanaman pala di Indonesia yaitu Maluku, Sulawesi Utara, Sumatra Barat, Aceh, Jawa Barat dan Papua. Salah satu kendala dari tanaman pala yaitu pada perkembangbiakannya, karena memiliki masa dormansi dua bulan yang disebabkan oleh kulit biji (tempurung) yang keras serta menyebabkan viabilitas dan vigor benih menjadi menurun. Salah satu cara mematahkan masa dormansi yaitu dengan pemberian larutan kimia golongan asam kuat seperti asam sulfat, berguna melunakkan kulit biji yang keras dan mempermudah proses imbibisi. Penelitian ini bertujuan untuk mengetahui pematahan dormansi berdasarkan uji viabilitas dan vigor benih serta mendapatkan konsentrasi asam sulfat yang paling baik dalam mematahkan dormansi benih pala. Penelitian menggunakan metode eksperimen Rancangan Acak Lengkap (RAL) dengan tiga kali ulangan. Perlakuan asam sulfat dengan empat konsentrasi yaitu $\mathrm{H}_{2} \mathrm{SO}_{4} 0 \%$ (kontrol) $\left(\mathrm{H}_{0}\right), \mathrm{H}_{2} \mathrm{SO}_{4} 10 \%\left(\mathrm{H}_{1}\right), \mathrm{H}_{2} \mathrm{SO}_{4} 20 \%\left(\mathrm{H}_{2}\right)$ dan $\mathrm{H}_{2} \mathrm{SO}_{4} 30 \%\left(\mathrm{H}_{3}\right)$. Parameter yang diamati adalah viabilitas dan vigor benih. Hasil penelitian menunjukkan aplikasi asam sulfat berpengaruh nyata terhadap viabilitas benih pala dengan nilai Sig < 0,05 dan mencapai $100 \%$ pada 56 HST. Hasil perhitungan vigor benih pala untuk indeks vigor mencapai 8,83 dan koefisien vigor 406.300. Asam sulfat konsentrasi $20 \%$ adalah konsentrasi yang paling baik untuk mematahkan masa dormansi benih pala pada 60 HST menjadi 14 HST berdasarkan uji viabilitas dan vigor benih.
\end{abstract}

Kata Kunci : Benih pala, Dormansi, Asam sulfat, Viabiltas, Vigor

\section{THE TESTING TO BREAK DORMANT USING SULFURIC ACID BASED ON VIABILITY AND VIGOR OF NUTMEG SEED (Myristica fragrans Houtt.)}

\begin{abstract}
The nutmeg plant (Myristica fragrans Houtt.) is known as one of the original spices found in Indonesia that has economical value. The area where the nutmeg grows in Indonesia is in Maluku, North Sulawesi, West Sumatra, Aceh, West Java, and Papua. One of the obstacles found in the nutmeg is its reproduction cycle, because it has a dormant state of two months that is caused by the thick and hard skin (shell) of the seed that causes the viability and vigor of the seed to decrease. One of the ways to break through the dormant state of the seed is to give it a chemical solution that is categorized as a strong acid such as sulfuric acid, which can soften the hard skin of the seed and easen the imbibition process. This research has the objective to figure out how to bypass the dormant state using seed vigor and viability tests and to obtain the purest concentrated sulfuric acid as well as the way to bypass the dormant state of the nutmeg seed. This research uses the Complete Randomized Design (CRD) three times repeatedly.Dosages using four different concentrations of sulfuric acid which are, $\mathrm{H}_{2} \mathrm{SO}_{4} 0 \%$ (controlled) $\left(\mathrm{H}_{0}\right), \mathrm{H}_{2} \mathrm{SO}_{4} 10 \%\left(\mathrm{H}_{1}\right), \mathrm{H}_{2} \mathrm{SO}_{4}$ $20 \%\left(\mathrm{H}_{2}\right)$ and $\mathrm{H}_{2} \mathrm{SO}_{4} 30 \%\left(\mathrm{H}_{3}\right)$. The parameters that are being observed are the viability and vigor of the seed. The results of the experiments show that with the sulfuric acid applied gives real-time seed viability and vigor reactions with the value of Sig < 0.05 and it can reach $100 \%$ on the 56 DAP. The results of the calculations show that the vigor of the nutmeg seed reaches an 8.83 vigor index and vigor coefficient of 406.300 . With a $20 \%$ concentrated sulfuric acid solution is the
\end{abstract}


concentration with the most efficient means of bypassing the dormant state of the nutmeg seed on with the 60 DAP becoming 14 DAP based on the seed viability and vigor test.

Keywords : Nutmeg Seed, Dormant, Sulfuric Acid, Viability, Vigor

\section{PENDAHULUAN}

Tanaman pala (Myristica fragrans Houtt.) dikenal sebagai tanaman rempah sejak abad ke-18 yang memiliki nilai ekonomis dan multiguna, karena setiap bagian dari tanaman ini dapat dimanfaatkan dalam berbagai industri (Suwarto, 2014). Tanaman pala merupakan tanaman rempah asli dari Provinsi Maluku (Purseglove et al., 1995 dalam Fauziyah et al., 2015). Karakteristik tanaman pala sebagai penghasil minyak atsiri meliputi myristicin dan fragrances. Myristicin yaitu komponen fenolik yang digunakan sebagai pengawet makanan. Fragances yaitu zat pewangi yang digunakan sebagai bahan dasar dalam industri sabun, parfum dan kosmetik (Mudlofar, 2012).

Negara Indonesia sampai saat ini merupakan produsen pala terbesar di dunia yaitu sebesar $70 \%$ diikuti Grenada, India, Srilangka, dan Malaysia. Bentuk ekspor dari tanaman pala meliputi buah pala berkulit, buah pala kupasan dan fuli pala (Sartika, 2011). Daerah penghasil utama pala di Indonesia antara lain kepulauan Maluku, Sulawesi Utara, Sumatera Barat, Aceh, Jawa Barat dan Papua (Dharma et al., 2015). Sebagai negara produsen tanaman pala terbesar, maka untuk mempertahankan produksi perlu mendapat perhatian khusus dalam perkembangbiakannya. Tanaman pala berkembangbiak dengan cara vegetatif yaitu dengan cangkok dan okulasi serta cara generatif dengan biji (Bustaman, 2008).

Biji dikatakan berkecambah jika telah terbentuk plumula dan radikula. Proses awal perkecambahan adalah imbibisi, yaitu masuknya air ke dalam biji sehingga kadar air dalam biji mencapai presentase tertentu. Keberhasilan biji dalam berkecambah ditentukan oleh faktor internal dan eksternal dari biji tersebut. Faktor internal yang mendukung perkecambahan yaitu zat perangsang tumbuh dan gen, sementara faktor eksternal meliputi suhu, kadar air, oksigen dan cahaya (Prawiranata et al., 1988).
Peristiwa dormansi yang terjadi pada biji tergantung dari tipe biji pada tanaman tersebut. Terdapat beberapa faktor yang secara umum menyebabkan terjadinya dormansi adalah keadaan fisik dari kulit biji, keadaan fisiologi dari embrio, dan kombinasi dari kedua keadaan tersebut (Sutopo, 2012). Biji pala mempunyai sifat dormansi yang disebabkan oleh kulit biji yang keras dan umumnya menghambat perkecambahan walaupun disemaikan pada kondisi perkecambahan yang optimum (Dharma et al., 2015)

Biji sebagian besar tumbuhan biasanya berkecambah dengan segera bila diberi air, didukung dengan suhu yang memadai, cahaya matahari, dan keadaan lingkungan yang sesuai. Beberapa tumbuhan, untuk bijinya tidak segera berkecambah meskipun telah diletakkan pada kondisi lingkungan yang mendukung. Biji tersebut mengalami dormansi

Biji yang mengalami dormansi terjadi penurunan viabilitas dan vigor. Kedua nilai ini memungkinkan biji tersebut untuk tumbuh menjadi normal meskipun keadaan pada lapangan produksi suboptimum. Viabilitas mencakup potensial berkecambah dan keserempakan perkecambahan. Viabilitas biji diartikan sebagai pertumbuhan dan perkembangan bagian-bagian penting embrio yang menunjukkan kemampuan untuk tumbuh normal pada lingkungan yang sesuai (Sutopo, 1993).

Vigor dicerminkan oleh indeks dan koefisien vigor. Tingkat vigor tinggi dapat dilihat dari kecambah yang tahan terhadap berbagai faktor pembatas yang mempengaruhi pertumbuhan dan perkembangannya. Ketahanan terhadap faktor pembatas juga dipengaruhi oleh mutu genetis yang dicerminkan oleh varietas (Sadjad et al., 1999). Dormansi sangat berpengaruh terhadap penurunan viabilitas dan vigor biji, maka untuk dapat mematahkan dormansi perlu dilakukan suatu perlakuan khusus secara kimia menggunakan asam sulfat. 
Penelitian yang dilakukan oleh Indriana (2016), menggunakan larutan asam sulfat terhadap viabilitas dan vigor benih jarak (Jatropha curcas Linn.) dapat memberikan persentasi daya kecambah benih sebesar 93,521\%. Penelitian yang dilakukan oleh Suyatmi et al. (2008) terhadap perkecambahan biji jati (Tectona grandis Linn.f), diperoleh pemberian asam sulfat $70 \%$ selama 30 menit dapat mematahkan masa dormansi benih jati. Penelitian yang dilakukan oleh Saila et al. (2016) tentang lama perendaman benih saga (Adenanthera pavonina L.) dalam asam sulfat $10 \%$ diperoleh perlakuan lama perendaman selama 30 menit mendapatkan hasil yang lebih tinggi dibandingkan perlakuan lainnya.

Berdasarkan uraian di atas dan ditinjau dari segi morfologi biji pala yang memiliki tempurung keras dan masa dormansi yang cukup panjang yaitu memerlukan waktu dua bulan untuk berkecambah (Tony et al., 2015). Maka, dilakukan penelitian pematahan dormansi biji pala menggunakan asam sulfat. Penelitian ini bertujuan untuk mengetahui pematahan dormansi dan mendapatkan konsentrasi asam sulfat yang paling baik berdasarkan viabilitas dan vigor benih pala.

\section{METODE PENELITIAN}

\section{Waktu dan Tempat}

Penelitian ini dilaksanakan pada bulan Desember Tahun 2017 sampai bulan April Tahun 2018 bertempat pada Laboratorium Biologi Dasar Program Studi Biologi, Fakultas Matematika dan Ilmu Pengetahuan Alam, Universitas Sam Ratulangi, Manado.

\section{Alat dan Bahan}

Alat yang digunakan dalam penelitian ini adalah: oven, timbangan analitik, gelas ukur, gelas kimia, pipet, konteiner plastik ukuran $38 \times 30 \times 15 \mathrm{~cm}$, sarung tangan, kertas label, kertas tissue, kamera dan alat tulis. Bahan yang digunakan meliputi: biji pala matang fisiologi, akuades, asam sulfat $\left(\mathrm{H}_{2} \mathrm{SO}_{4}\right)$, dan media tanam tanah bercampur pasir.

\section{Rancangan Penelitian}

Penelitian ini menggunakan metode eksperimen Rancangan Acak Lengkap dengan tiga kali penggulangan. Perlakuan asam sulfat yang diberikan adalah: konsentrasi $\mathrm{H}_{2} \mathrm{SO}_{4} 0 \%$ (kontrol) $\left(\mathrm{H}_{0}\right), \mathrm{H}_{2} \mathrm{SO}_{4}$ $10 \%\left(\mathrm{H}_{1}\right), \mathrm{H}_{2} \mathrm{SO}_{4} 20 \%\left(\mathrm{H}_{2}\right)$ dan $\mathrm{H}_{2} \mathrm{SO}_{4} 30 \%$ $\left(\mathrm{H}_{3}\right)$.

\section{Prosedur Penelitian}

\section{Persiapan sampel}

Biji berasal dari buah yang telah masak penuh (matang fisiologi) diambil dari perkebunan warga di Desa Tombuluan, Kabupaten Minahasa, Provinsi Sulawesi Utara. Buah pala dipisahkan dari bijinya kemudian dibersihkan dari fuli dan dicuci bersih. Sebelum diberi perlakuan, dilakukan pemilihan biji dengan cara direndam dalam wadah yang berisi air. Metode ini, dirujuk dari penelitian yang dilakukan oleh Lestari (2016). Biji pala yang tenggelam dipilih untuk digunakan sebagai sampel penelitian, yang selanjutnya disebut dengan benih. Selanjutnya benih pala dikeringanginkan pada suhu ruangan selama 90 menit dan ditimbang untuk mendapatkan sampel yang homogen. Berat sampel biji pala yang digunakan antara 8,00 - 9,00 g.

Selanjutnya diambil 10 biji pala untuk pengukuran kadar air dengan metode oven selama 4 jam pada suhu $105^{\circ} \mathrm{C}$. Suhu ini digunakan untuk benih yang mengandung minyak-minyak atsiri (Sutopo, 1993). Berikutnya diambil 10 biji pala untuk pengukuran daya imbibisi biji kemudian ditimbang dan direndam dalam konteiner plastik yang berisi akuades selama dua jam selanjutnya ditimbang kembali.

Media tanam yang digunakan yaitu tanah bercampur pasir dengan perbandingan 1:1. Metode ini dirujuk dari penelitian yang dilakukan oleh Yuniarti et al. (2015). Pasir dapat digunakan untuk menurunkan tingkat kekerasan tanah sehingga akar lebih mudah menembus tanah. (Hakim et al., 1986 dalam Bukhari, 2013).

\section{Perlakuan}

Biji pala direndam dalam asam sulfat sesuai perlakuan, yaitu $\mathrm{H}_{2} \mathrm{SO}_{4} 0 \%$ (kontrol) $\left(\mathrm{H}_{0}\right), \mathrm{H}_{2} \mathrm{SO}_{4} 10 \%\left(\mathrm{H}_{1}\right), \mathrm{H}_{2} \mathrm{SO}_{4} 20 \%\left(\mathrm{H}_{2}\right)$ dan $\left(\mathrm{H}_{2} \mathrm{SO}_{4} 30 \%\left(\mathrm{H}_{3}\right)\right.$ sebanyak 12 benih untuk tiap ulangan selama 30 menit metode ini 
dirujuk dari penelitian yang dilakukan oleh Nengsih (2017). Selanjutnya setelah direndam, biji pala dibilas dengan akuades untuk menghilangkan $\mathrm{H}_{2} \mathrm{SO}_{4}$ yang masih menempel pada kulit tempurung benih metode ini dirujuk dari penelitian yang dilakukan oleh Lestari et al. (2016). Kemudian benih pala ditanam dalam media tanam dengan kedalaman $2 \mathrm{~cm}$. Metode ini dirujuk dari penelitian yang dilakukan oleh Ramadhani et al. (2015).

\section{Pemeliharaan dan Pengamatan}

Pemeliharaan berupa penyiraman air dengan volume sama sebanyak $50 \mathrm{ml}$ untuk tiap benih pada semua perlakuan dan dilakukan sekali sehari. Metode ini dirujuk dari penelitian oleh Mokodompit (2005). Pengamatan dilakukan setiap hari dengan mencatat setiap biji yang mulai berkecambah, dimana kriteria kecambah diawali dengan munculnya radikula dan plumula.

\section{Parameter yang Diukur}

1. Viabilitas Biji

Viabilitas biji dapat diukur dengan parameter yang dikelompokkan menurut ISTA dalam Lesilolo et.al., (2013) sebagai berikut:

a. Potensi Berkecambah (PB)

$$
P B=\frac{\text { Jumlah kecambah hidup }}{\text { Jumlah biji }} \times 100 \%
$$

b. Keserempakan Perkecambahan (KP)

$$
K P=\frac{\begin{array}{c}
\text { Jumlah kecambah hidup } \\
\text { pada tengah waktu } \\
\text { perkecambahan }
\end{array}}{\begin{array}{c}
\text { Jumlah biji yang } \\
\text { dikecambahkan }
\end{array}} \times 100 \%
$$

\section{Vigor Biji}

Kecepatan berkecambah yang dilihat dari vigornya, dapat dihitung menggunakan rumus menurut Nengsih. (2017)) sebagai berikut:

a. Indeks Vigor

Indeks Vigor $=\frac{G_{1}}{D_{1}}+\frac{G_{2}}{D_{2}}+\ldots \ldots \frac{G_{n}}{D_{n}}$

b. Koefisien Vigor
Koefisien Vigor

$$
=100\left(G_{1} D_{1}+\cdots G_{n} D_{n}\right)
$$

Dimana:

G: Jumlah kecambah pada hari tertentu

D: Waktu yang berkoresponden

dengan jumlah kecambah tersebut.

\section{Analisis Data}

Data yang diperoleh dari hasil penelitian kemudian dianalisis dengan menggunaka Analisis Varian (ANAVA) dan jika signifikan dilanjutkan dengan uji BNT dengan taraf nyata 0,05 .

\section{HASIL DAN PEMBAHASAN}

Peristiwa dormansi biasanya terjadi akibat dari embrio, kulit biji dan faktor lingkungan (Prawiranata et al., 1988). Peristiwa dormansi dapat dipatahkan dengan berbagai metode perlakuan secara kimia, mekanis dan lainnya. Penelitian ini telah dilakukan dengan perlakuan kimia menggunakan asam sulfat pada konsentrasi yang berbeda.

Penelitian diawali dengan pengukuran kadar air dan daya imbibisi benih. Nilai rata-rata hasil perhitungan kadar air benih pala yaitu 6,25\%. Kadar air optimum bagi sebagian besar benih adalah 6$8 \%$. Kadar air yang terlalu tinggi dapat menyebabkan biji berkecambah sebelum ditanam sedangkan terlalu rendah menyebabkan kerusakan pada embrio (Sutopo, 1993). Maka, dengan demikian benih pala yang digunakan sebagai sampel telah memenuhi persyaratan kadar air. Kadar air adalah presentase kandungan air suatu bahan, yang sangat berpengaruh terhadap mutu bahan (Syarief dan Halid, 1991)

Nilai rata-rata daya imbibisi benih pala yang diperoleh yaitu $0,32 \mathrm{~g}$. Daya imbibisi menyatakan kemampuan benih untuk menyerap air yang diperlukan. Imbibisi merupakan tahapan awal dari perkecambahan (Prawiranata et al., 1988). 
Tabel 1. Rerata Potensial Berkecambah (\%) Benih Pala (Myristica fragrans)

\begin{tabular}{cccccc}
\hline Perlakuan & \multicolumn{5}{c}{ Hari Sesudah Tanam (HST) } \\
\cline { 2 - 6 } & 14 & 28 & 42 & 56 & 60 \\
\hline $\begin{array}{c}\mathrm{H}_{2} \mathrm{SO}_{4} 0 \%\left(\mathrm{H}_{0}\right) \\
\left\{\mathrm{Kontrol}^{\prime}\right.\end{array}$ & $0^{\mathrm{a}}$ & $0^{\mathrm{a}}$ & $11,10^{\mathrm{a}}$ & $80,55^{\mathrm{a}}$ & 100 \\
\hline $\begin{array}{c}\mathrm{H}_{2} \mathrm{SO}_{4} 10 \% \\
\left(\mathrm{H}_{1}\right)\end{array}$ & $36,10^{\mathrm{c}}$ & $86,10^{\mathrm{c}}$ & $100^{\mathrm{c}}$ & $100^{\mathrm{b}}$ & 100 \\
\hline $\mathrm{H}_{2} \mathrm{SO}_{4} 20 \%$ \\
$\left(\mathrm{H}_{2}\right)$
\end{tabular}

\section{Viabilitas Biji}

a. Potensial Berkecambah (PB)

Tabel 2. Analisis Varian Potensial

Berkecambah

Benih Pala (Myristica fragrans)

\begin{tabular}{ccc}
\hline $\begin{array}{c}\text { Potensial } \\
\text { Berkecambah }\end{array}$ & Nilai F & Sig \\
\hline 14 HST & 29,455 & $0,00 *$ \\
28 HST & 193,336 & $0,00 *$ \\
42 HST & 969,838 & $0,00 *$ \\
56 HST & 12,263 & $0,02 *$ \\
\hline
\end{tabular}

Ket: $*$ Sig $<0,05$

Pengamatan pada 14 HST perlakuan $\mathrm{H}_{2} \mathrm{SO}_{4} 20 \%\left(\mathrm{H}_{2}\right)$ menunjukkan nilai potensial berkecambah tertinggi yaitu $49,99 \%$. Selanjutnya diikuti perlakuan $\mathrm{H}_{2} \mathrm{SO}_{4} \quad 10 \%$ $\left(\mathrm{H}_{1}\right)$ yaitu $36,10 \%$, perlakuan $\mathrm{H}_{2} \mathrm{SO}_{4} 30 \%$ $\left(\mathrm{H}_{3}\right)$ yaitu 22,22\%. Nilai potensial berkecambah terendah pada perlakuan $\mathrm{H}_{2} \mathrm{SO}_{4}$ $0 \%\left(\mathrm{H}_{0}\right)$ yaitu $0 \%$. Pengamatan pada $28 \mathrm{HST}$, perlakuan $\mathrm{H}_{2}$ menunjukkan nilai potensial berkecambah tertinggi yaitu 91,66\%, diikuti perlakuan $\mathrm{H}_{1}$ yaitu $86,10 \%$, perlakuan $\mathrm{H}_{3}$ yaitu $38,88 \%$. Nilai potensial berkecambah terendah pada perlakuan $\mathrm{H}_{0}$ yaitu $0 \%$ (Tabel $1)$.

Pengamatan pada 42 HST untuk perlakuan $\mathrm{H}_{2}$ dan $\mathrm{H}_{1}$ nilai potensial berkecambah telah mencapai $100 \%$, dan kemudian diikuti perlakuan $\mathrm{H}_{3}$ yaitu 91,66\% dan terendah pada perlakuan $\mathrm{H}_{0}$ (kontrol) yaitu 11,10\%. Pada pengamatan 56 HST untuk perlakuan $\mathrm{H}_{2}, \mathrm{H}_{1}$ dan $\mathrm{H}_{3}$ telah mencapai $100 \%$ dan terendah pada perlakuan $\mathrm{H}_{0}$ (kontrol) yaitu $80,55 \%$. Pada pengamatan 60 HST semua perlakuan telah mencapai nilai potensial berkecambah yang sama yaitu 100\% (Tabel 1).

Hasil potensial berkecambah benih pala pada $60 \mathrm{HST}$ perlakuan $\mathrm{H}_{1}, \mathrm{H}_{2}$, dan $\mathrm{H}_{3}$ telah mencapai nilai $100 \%$. Hal ini berarti setiap benih pala pada ketiga perlakuan tersebut telah berkecambah dan dormansi benih pala telah berhasil dipatahkan atau diperpendek masa dormansi. Hal ini sesuai dengan literatur yang menjelaskan bahwa asam kuat sangat efektif untuk mematahkan dormansi pada biji yang memiliki struktur kulit keras. Asam sulfat sebagai asam kuat dapat melunakan kulit biji yang keras sehingga dapat dilalui oleh air dengan mudah dan proses perkecambahan menjadi lebih cepat (Gardner et al., 1991),

Pada perlakuan $\mathrm{H}_{0}$ (kontrol) benih pala baru berkecambah saat hari ke-41 pada perhitungan waktu 42 HST. Peristiwa ini berarti telah memenuhi teori dan waktu perkecambahan benih pala sebenarnya atau tanpa perlakuan asam sulfat yaitu selama 60 hari (dua bulan). Benih pala yang apabila diberikan perlakuan asam sulfat maka waktu berkecambah menjadi lebih singkat yaitu 14 HST telah berkecambah (Tabel 2).

Hasil penelitian yang dilakukan oleh Ramadhani et al. (2015), menyimpulkan bahwa perlakuan pematahan dormansi secara kimia yang terbaik untuk meningkatkan kecambah dan indeks vigor serta 
mempercepat laju perkecambahan adalah perlakuan perendaman dengan asam sulfat

Konsentrasi larutan asam sulfat yang paling baik dalam mematahkan dormansi benih pala yaitu konsentrasi $20 \%$, dengan presentase potensi tumbuh sebanyak 49,99\% dalam waktu 14 HST. Hal ini sesuai dengan hasil penelitian oleh Hedty et al. (2014), yang menunjukkan hasil konsentrasi asam sulfat $20 \%$ dengan air kelapa 100\% lebih cepat melunakkan kulit biji kopi arabika sebanyak $86,66 \%$, dibandingkan dengan perlakuan faktorial lainnya.

Penelitian yang dilakukan oleh Yuniarti et al. (2015) tentang teknik pematahan dormansi untuk mempercepat perkecambahan benih kourbaril (Hymenaea courbaril) memperoleh hasil perendaman dalam larutan asam sulfat dapat mematahkan dormansi dan meningkatkan perkecambahan. Penelitian yang dilakukan oleh Yuniarti (1997) tentang perlakuan benih Merbabu (Intsia bijuga) dengan perendaman asam sulfat konsentrasi $20 \%$ dapat meningkatkan kecepatan tumbuh hingga 82,6\%. Larutan asam sulfat pada konsentrasi yang sesuai dapat melunakkan lapisan lilin pada kulit biji yang keras dan tebal. Penelitian yang dilakukan oleh Nengsih (2017) yaitu penggunaan larutan kimia dalam pematahan dormansi benih kopi liberika, memperoleh hasil dalam larutan asam sulfat dengan konsentrasi $20 \%$ selama 30 menit dapat mematahkan dormansi benih kopi.

Sutopo (2012), menyatakan bahwa larutan asam kuat seperti asam sulfat dapat digunakan dengan konsentrasi yang bervariasi sampai konsentrasi pekat tergantung jenis biji yang diperlakukan sehingga kulit biji menjadi lunak. Larutan asam sulfat dapat menguraikan komponen dinding sel pada biji, sehingga dinding sel lebih permeabel dan proses imbibisi pada biji berlangsung dengan baik (Suyatmi et al., 2008). Dinding sel tersusun atas mikrofibil selulosa yang terdiri dari polisakarida. Biji yang diberi perlakuan dengan asam sulfat dapat memutuskan ikatan mikrofibril selulosa yang menyebabkan dinding sel menjadi permeabel, sehingga air dan oksigen dapat lebih cepat masuk ke dalam sel biji. Air dan oksigen yang masuk ke dalam sel biji dibutuhkan untuk respirasi embrio (Lestari et al., 2016).

Benih yang telah menunjukkan tanda-tanda tumbuh seperti tumbuhnya radikula dan plumula dikatakan telah ada potensi untuk bertumbuh. Potensi bertumbuh adalah presentase biji yang menunjukkan gejala tumbuh dalam pengujian langsung, dinyatakan bertumbuh apabila radikula dan plumula tumbuh dan menembus kulit biji. Potensi tumbuh sangat dipengaruhi oleh faktor fisiologi dan lingkungan (Sadjad et al., 1999). Benih pala yang telah berhasil dipatahkan dormansi telah bertumbuh menjadi kecambah dan melalui beberapa proses metabolisme. Secara biologis terjadi beberapa proses metabolisme dalam tahapan perkecambahan yaitu penyerapan air (imbibisi), pencernaan, pengangkutan zat makanan, asimilasi, respirasi dan pertumbuhan (Gumelar, 2015).

Tabel. 3 Keserempakan Perkecambahan Biji Pala (Myristica fragrans)

\begin{tabular}{lccc}
\hline Perlakuan & $\begin{array}{c}\text { Banyaknya } \\
\text { Benih }\end{array}$ & $\begin{array}{c}\text { Keserempakan } \\
\text { Perkecambahan }(\%)\end{array}$ \\
\hline $\mathrm{H}_{2} \mathrm{SO}_{4}$ & $0 \%\left(\mathrm{H}_{0}\right)$ (Kontrol) & 0 & $0^{\mathrm{a}}$ \\
$\mathrm{H}_{2} \mathrm{SO}_{4}$ & $10 \%\left(\mathrm{H}_{1}\right)$ & 2 & $5,55^{\mathrm{a}}$ \\
$\mathrm{H}_{2} \mathrm{SO}_{4}$ & $20 \%\left(\mathrm{H}_{2}\right)$ & 2 & $5,55^{\mathrm{a}}$ \\
$\mathrm{H}_{2} \mathrm{SO}_{4}$ & $30 \%\left(\mathrm{H}_{3}\right)$ & 0 & $0^{\mathrm{a}}$ \\
\hline
\end{tabular}




\section{b. Keserempakan Perkecambahan (KP)}

Tabel 4. Hasil Analisis Varian Keserempakan Perkecambahan Biji Pala (Myristica fragrans)

\begin{tabular}{cccc}
\hline $\begin{array}{c}\text { Keserempakan } \\
\text { PPerkecambahan }\end{array}$ & Nilai F & Sig. \\
\hline $30 \mathrm{HST}$ & 2,667 & 0,119 & \\
\hline
\end{tabular}

Ket: $*$ Sig $<0,05$

Hasil untuk nilai keserempakan perkecambahan pada pengamatan 30 HST untuk perlakuan $\mathrm{H}_{1}$ dan $\mathrm{H}_{2}$ yaitu 5,55\%, perlakuan $\mathrm{H}_{0}$ dan $\mathrm{H}_{3}$ yaitu $0 \%$. Nilai keserempakan perkecambahan dari biji pala yang rendah disebabkan setelah diberi perlakuan asam sulfat, benih pala tidak tumbuh serempak. Hasil menunjukkan perkecambahan yang terjadi pada setiap perlakuan berbeda-beda yaitu perlakuan $\mathrm{H}_{0}$ terjadi perkecambahan pada 41 - 60 HST, perlakuan $\mathrm{H}_{1}$ pada 21 - $34 \mathrm{HST}$, perlakuan $\mathrm{H}_{2}$ pada 14 - 30 HST dan perlakuan $\mathrm{H}_{3}$ pada 23 - 46 HST (Tabel 3).

Nilai hasil untuk keserempakan perkecambahan akan tinggi jika biji pala tidak diberi perlakuan. Perlakuan asam sulfat dengan konsentrasi berbeda akan memberikan respon perkecambahan yang berbeda dan akhirnya mempengaruhi nilai KP.

Nilai hasil untuk keserempakan perkecambahan benih pala pada 30 HST tidak berbeda nyata pada taraf uji 0,05 dengan nilai Sig $>0,05$. Berarti perlakuan asam sulfat tidak berpengaruh terhadap keserempakan dari perkecambahan. Keserempakan tumbuh berkaitan dengan kemampuan memanfaatkan cadangan energi dalam masing-masing biji untuk manjadi kecambah (Sadjad et al., 1999) (Tabel 4).

\section{Vigor benih}

Pengujian vigor benih sangat diperlukan dalam informasi mutu benih. Vigor adalah kemampuan benih untuk tumbuh normal pada semua keadaan lingkungan (Widajati et al., 2013).

Vigor benih dicerminkan oleh dua nilai penting yaitu indeks vigor dan koefisien vigor. Kedua nilai ini menempatkan kemampuan benih untuk tumbuh normal pada semua kondisi lapang maupun setelah benih melalui periode simpan lama (Sutopo, 1993).

Berdasarkan hasil dari perhitungan nilai vigor diperoleh nilai indeks vigor benih pala yaitu 8,83 dan nilai koefisien vigor benih pala yaitu 406.300 . Benih yang mempunyai koefisien vigor lebih besar dari 30 merupakan benih yang memiliki kecepatan tumbuh yang lebih kuat. (Sadjad, 1993).

Benih yang bervigor tinggi mampu menunjukkan kinerja yang baik dalam proses perkecambahan dalam kondisi lingkungan yang beragam (ISTA, 2007). Pengujian vigor benih sangat diperlukan dalam informasi mutu benih. Vigor adalah kemampuan benih untuk tumbuh normal pada semua keadaan lingkungan (Widajati et al., 2013).

\section{KESIMPULAN}

Berdasarkan penelitian yang telah dilakukan dan hasil yang diperoleh, maka disimpulkan, bahwa perlakuan asam sulfat dapat mematahkan dormansi benih pala (Myristica fragrans) dari 60 hari menjadi 14 hari serta dapat meningkatkan viabilitas dan vigor benih pala. Perlakuan asam sulfat $20 \%$ $\left(\mathrm{H}_{2}\right)$ berdasarkan uji viabiltas dan vigor.

\section{DAFTAR PUSTAKA}

Bukhari. 2013. Pengaruh Konsentrasi $\mathrm{KNO}_{3}$ dan Lama Perendaman Terhadap Viabilitas dan Vigor Benih Pepaya (Carica papaya L). [Skripsi]. Prodi Agroekoteknologi, Fakultas Pertanian, Universitas Teukur Umar Meulaboh, Aceh Barat.

Bustaman, S. 2008. Prospek Pengembangan Minyak Pala Banda Sebagai Komoditas Ekspor Maluku. Jurnal Litbang Pertanian 27(3): 93-98.

Dharma, P.E.S., S. Samudin dan Adrianton. 2015. Perkecambahan Benih Pala (Myristica fragrans Houtt.) dengan Metode Skarifikasi dan Perendaman ZPT Alami. Jurnal Agrotekbis 3(2): 158-167.

Fauziyah, E., D.P. Kuswantoro dan Sanudin. 2015. Prospek Pengembangan Pala (Myristica fragrans Houtt.) di Hutan Rakyat. Jurnal Kehutanan 9(1): 32-39. 
Gardner, F.P., R.B. Pearce and R.L. Mitchell. 1991. Physiology of Crop Plants. Terjemahan Susilo, $\mathrm{H}$ dan Subiyanto. Universitas Indonesia Press, Jakarta.

Gumelar, A.I. 2015. Pengaruh Kombinasi Larutan Perendaman dan Lama Penyimpanan Terhadap Viabilitas, Vigor dan Dormansi Benih Padi Hibrida Kultivar SL-8. Jurnal Agrorektan (2)2: 125-135.

Hedty., Mukarlina dan M. Turnip. 2014. Pemberian $\mathrm{H}_{2} \mathrm{SO}_{4}$ dan Air Kelapa pada Uji Viabilitas Biji Kopi Arabika (Coffea arabika L.). Jurnal Protobiont 3(1): 7-11.

Indriana, K.R. 2016. Pengaruh Waktu Penyimpanan Benih dan Konsentrasi Larutan Asam Sulfat Terhadap Viabilitas dan Vigor Benih Jarak (Jatropha curcas Linn.) di Persemaian. Jurnal Siliwangi 2(1): 71-76.

ISTA. 2007. Germination and Seedling Establishment Chapter 10(4): Seed Quality, Influence on Germination. www.sl.kvi.dk/upload/chapter 10001.pdf.2000.

Lesilolo, M.K., J. Riry dan E.A. Matatula. 2013. Pengujian Viabilitas dan Vigor Benih Beberapa Jenis Tanaman yang Beredar di Pasaran Kota Ambon. Jurnal Agrologia 2(1): 1-9.

Lestari, D., R. Linda dan Mukarlina. 2016. Pematahan Dormansi dan Perkacambahan Biji Kopi Arabica (Coffea Arabica L.) dengan Asam Sulfat $\left(\mathrm{H}_{2} \mathrm{SO}_{4}\right)$ dan Giberelin $\left(\mathrm{GA}_{3}\right)$. Jurnal Protobiont 5(1): 8-13.

Mokodompit, M.T. 2005. Perkecambahan Biji Pala (Myristica fragrans Houtt.) dengan Pemberian Gibberellin dan Auksin. [Skripsi]. Jurusan Biologi, FMIPA, UNSRAT, Manado.

Mudlofar, D. 2012. Analisis Komposisi Minyak Atsiri Fuli dan Biji Pala Papua (Myristica argentea Warb.) dengan GC-MS. [Skripsi]. Fakultas Teknologi Pertanian, IPB, Bogor.
Nengsih, Y. 2017. Penggunaan Larutan Kimia Dalam Pematahan Dormansi Benih Kopi Liberika. Program Studi Agroteknologi, Fakultas Pertanian Universitas Batanghari. Jurnal Media Pertanian 2(2): 85-91.

Prawiranata, W., P. Tjondronegoro., dan S. Harran. 1988. Dasar-dasar Fisiologi Tumbuhan. Fakultas Pertanian. IPB, Bogor.

Ramadhani, S. Haryati dan J. Ginting. 2015. Pengaruh Perlakuan Pematahan Dormansi Secara Kimia Terhadap Viabilitas Benih Delima (Punica granatum L.). Jurnal Agroekoteknologi 3(2): 590-594.

Sadjad, S., R. Murniati dan S. Iliyas. 1999. Parameter Pengujian Vigor Benih dari Komparatif ke Simulative. Grasindo, Jakarta.

Saila, J., M. Mardhiansyah dan T. Arlita. 2016. Lama Waktu Perendaman Benih Menggunakan Asam sulfat $\left(\mathrm{H}_{2} \mathrm{SO}_{4}\right)$ Terhadap Daya Kecambah dan Pertumbuhan Semai Saga (Adenanthera pavonina L.). JomFaperta. 3(1): 1-6.

Sartika. 2011. Perkembangan Buah Pala di Indonesia. Rajawali Press, Jakarta.

Suyatmi, E., D. Hastuti dan S. Darmanti. 2008. Pengaruh Lama Perendaman dan Konsentrasi Asam Sulfat $\left(\mathrm{H}_{2} \mathrm{SO}_{4}\right)$ terhadap Perkecambahan Benih Jati (Tectona grandis Linn.). F.MIPA, UNDIP.

Sutopo L. 1993. Teknologi Biji. Rajawali Press, Jakarta.

Sutopo L. 2012. Teknologi Biji. Edisi Revisi. Rajawali Press, Jakarta.

Suwarto. 2014. Budidaya Pala Komoditas Ekspor. Kanisius, Yogyakarta.

Syarif, R., dan H. Halid. 1991. Teknologi Penyimpanan Pangan. Penerbit Arcan, Jakarta.

Tony., Bahrudin., dan I. Lapanjang. 2015. Perkecambahan dan Pertumbuhan Benih Pala (Myristica fragrans Houtt.) Akibat Lama Perendaman Pada Atonik dan Komposisi Media Tanam. e-Jurnal Mitra Sains 3(2): 96-108. 
Yuniarti, N. 1997. Penentuan Cara Perlakuan Pendahuluan Benih Merbabu (Intsia bijuga). Balai Teknologi Perbenihan, Balitbang Kehutanan Bogor, Bogor.

Yuniarti. N., dan D.F. Djaman. 2015. Teknik Pematahan Dormansi untuk Mempercepat Perkecambahan Benih Kourbaril (Hymenaea courbaril). Pross Sem Nas Masy Biodiv Indon. 1(6): 1443-1437.

Widajati, E., E. Murniati., E.R. Palupi.,T. Kartika., M.R. Suhartanto., dan A. Qadir. 2013. Dasar Ilmu dan Teknologi Benih. IPB, Bogor. 